\title{
Ecophysiology of 8 woody multipurpose species from semiarid northeastern Mexico
}

\author{
H. Stienen ${ }^{1}$, M.P. Smits ${ }^{2}$, N. Reid ${ }^{3}$, J. Landa ${ }^{4}$ and J.H.A. Boerboom² \\ 1 Institut Bicontrol GmbH, PF 1630, 6500 Mainz, F.R.G., \\ 2 Landbouw Universiteit Wageningen, Vakgroep Bosteelt \& Boscecologie, The Netherlands, \\ 3 Department of Plant Ecology, University of New England, Armidale, Australia, and \\ ${ }^{4}$ Facultad de Ciencias Forestales, UANL, Linares N.L., Mexico
}

\section{Introduction}

The Tamaulipan thornscrub is a low dry forest and shrubland complex covering about 20 million hectares of the Guifi coastal plain in northeastern Mexico and southern Texas, the region is called the Matorral. The Tamaulipan thornscrub has been grazed by domestic stock for about 4 centuries and is heavily exploited by subsistence farmers for fuel, timber and other resources (Reid et al., 1989). In order to prevent further desertification and sustain agricultural, livestock and forestry production, the Matorral must be conserved and, where necessary, enriched with desirable multipurpose trees and shrubs (MPTS).

The Facultad de Ciencias Forestales of the Universidad Autonoma de Nuevo Leon (UANL, Mexico), is applying a holistic agroforestry approach to some of the region's landuse problems (Stienen, 1989). Native shrubs and trees have been selected for agroforestry trials to date on the basis of the products and expected productivity. Knowledge of their ecophysiological characteristics would facilitate selection of the species most apt for silvicultural management under specified conditions. The water use/productivity ratio may be a useful be index for screening potential forestry species because drought frequeritly limits growth.

\section{Materials and Methods}

The study was conducted in the Matorral on the UANL campus, $10 \mathrm{~km}$ south of Linares $\left(24^{\circ} 47^{\prime} \mathrm{N}, 99^{\circ} 32^{\prime} \mathrm{W}\right)$, in spring and summer 1988. Mean annual rainfall is $749 \mathrm{~mm}$. Droughts occur in midsummer and winter. Annual free evaporation is 3 times the average precipitation (Car'stens, 1987).

The study site was a representative area of the Matorral growing on a Vertisol. Photosynthesis and transpiration were recorded with a portable Li-6200 (McDermitt, 1987). Comparable data for each species were collected by taking 20 sequential measurements under identical climatic conditions and by monitoring the diurnal changes of all species on days of extreme (wet, dry) environmental conditions. The water use efficiency of photosynthesis (WUEP) was calculated as photosynthetic rate $\left(\mu \mathrm{mol} \cdot \mathrm{m}^{-2} \cdot \mathrm{s}^{-1}\right)$ over transpiration rate $\left(\mathrm{mmol} \cdot \mathrm{m}^{-2} \cdot \mathrm{s}^{-1}\right)$. Water potentials were taken with a pressure bomb. Climatological data and 
soil water, expressed as the percentage of dry weight, were monitored throughout the study. Photosynthetically active radiation (PAR, $\mu \mathrm{mol} \cdot \mathrm{m}^{-2} \cdot \mathrm{s}^{-1}$ ) was measured over $1 \mathrm{~h}$ periods above and below the canopy. Eight native species were tested and assigned a relative rank from 1 to 8 for each of the parameters on the basis of the degree of drought adaptation. These ranks are summarized in a final drought adaptation ranking.

\section{Results and Conclusions}

Relative humidity fell as low as $20 \%$ when midday temperatures were $40^{\circ} \mathrm{C}$. In May, before the first rains, soil moisture content was $16 \%$ at $10 \mathrm{~cm}$ depth, $17 \%$ at $30 \mathrm{~cm}$ and $18 \%$ at $90 \mathrm{~cm}$. After $149 \mathrm{~mm}$ of rain in June, values were twice as high in the upper soil horizons but were invariant at $90 \mathrm{~cm}$ depth. By August, soil moisture had again dropped to the May levels, around the permanent wilting point.

Periods of light saturation for $\mathrm{CO}_{2}$ assimilation ( $P A R>500 \mu \mathrm{mol} \cdot \mathrm{m}^{-2} \cdot \mathrm{s}^{-1}$, Long and Hallgren, 1985) lasted for more than 8 $h$ above the tree crown and $6 \mathrm{~h}$ within the canopy in summer, indicating that conditions were unsuitable for the development of shade leaves.

The ecophysiological data for the 8 species are presented in Table $I$ and as a case study in Figs. 1 and 2. Photosynthesis and transpiration rates are means of the data for the most humid and driest days, and were used to calculate water use efficiency. The values were generally $20-40 \%$ higher under wet conditions, even WUEP, thus none of the species showed evidence of extraordinary drought adaptation. The 2 Amyris species had the best WUEP ratios and Diospyros texana and Celtis pallida the lowest. Fig. 2 presents diurnal curves for the 2 species that exhibited the greatest contrast in WUEP. Species differed in their abilities to achieve a high rate of photosynthesis with moderate water use in the mornings, and only the more drought-resistant species reopened stomata in the afternoons. The water potentials of the latter species fell to $-7.0 \mathrm{MPa}$ under dry conditions, while the

Table I. Decision table with the most important ecophysiological and ecological parameters expressed as diurnal means or ranks and the mean ranking value for the species based on 1-8 (worst to best) points for each parameter and the final ranks of the species regarding their drought adaptation, based on means of 10 wet and 10 dry days.

\begin{tabular}{|c|c|c|c|c|c|c|c|c|c|c|c|c|}
\hline \multirow[t]{3}{*}{ Species } & \multicolumn{2}{|c|}{ WUEP } & \multicolumn{2}{|l|}{ A } & \multicolumn{2}{|l|}{$E$} & \multirow{2}{*}{\multicolumn{2}{|c|}{$\begin{array}{l}\text { Stomata } \\
\text { open } \\
\text { (afternoon) }\end{array}$}} & \multirow{3}{*}{$\begin{array}{l}\text { Shade } \\
\text { leaf } \\
\text { production }\end{array}$} & \multirow{3}{*}{$\begin{array}{l}\text { Dropping } \\
\text { leaves } \\
\text { with } \\
\text { drought }\end{array}$} & \multirow{3}{*}{$\begin{array}{l}\text { Mean } \\
\text { rank } \\
\text { value }\end{array}$} & \multirow[t]{3}{*}{ Rank } \\
\hline & \multirow[t]{2}{*}{$d r y$} & \multirow[t]{2}{*}{ wet } & \multirow[t]{2}{*}{$d r y$} & \multirow[t]{2}{*}{ wet } & \multirow[t]{2}{*}{$d r y$} & \multirow[t]{2}{*}{ wet } & & & & & & \\
\hline & & & & & & & $d r y$ & wet & & & & \\
\hline Helietta parvifolia & 2.6 & 3.4 & 2.4 & 4.0 & 2.1 & 1.3 & 3 & 6 & 4 & 5 & 3.8 & 2 \\
\hline Amyris madrensis & 2.7 & 4.0 & 3.2 & 4.6 & 2.1 & 1.8 & 7 & 8 & 2 & 8 & 5.6 & 8 \\
\hline Amyris texana & 2.7 & 4.7 & 2.7 & 4.5 & 1.4 & 1.4 & 8 & 7 & 7 & 7 & 5.4 & 7 \\
\hline Gochnatia hypoleuca & 1.9 & 3.3 & 3.1 & 5.2 & 1.9 & 3.1 & 6 & 5 & 8 & 6 & 4.9 & 6 \\
\hline Condalia hookeri & 2.4 & 2.9 & 6.2 & 7.0 & 2.8 & 2.8 & 2 & 4 & 1 & 1 & 4.5 & 4 \\
\hline Diospyros texana & 1.4 & 1.9 & 3.4 & 2.3 & 1.1 & 1.1 & 4 & 3 & 6 & 4 & 3.3 & 1 \\
\hline Celtis pallida & 1.7 & 2.5 & 3.3 & 6.6 & 3.1 & 3.1 & 1 & 1 & 3 & 3 & 3.9 & 3 \\
\hline Cordia boissieri & 2.7 & 2.2 & 2.7 & 6.1 & 4.0 & 4.4 & 5 & 2 & 5 & 2 & 4.6 & 5 \\
\hline
\end{tabular}

Stomatal opening was based on dimensionless stomatal resistance.

WUEP: water use efficiency of photosynthesis $\left(\mu \mathrm{mol} \mathrm{CO} 2 / \mathrm{mmol} \mathrm{H}_{2} \mathrm{O}\right)$; $A$ : daily mean $\mathrm{CO}_{2}$ net assimilation $\left(\mu \mathrm{mol} \cdot \mathrm{m}^{-2} \cdot \mathrm{s}^{-1}\right)$; $E$ : daily mean transpiration $\left(\mathrm{mmol} \cdot \mathrm{m}^{-2} \cdot \mathrm{s}^{-1}\right)$ 
$456 \mathrm{~s}$

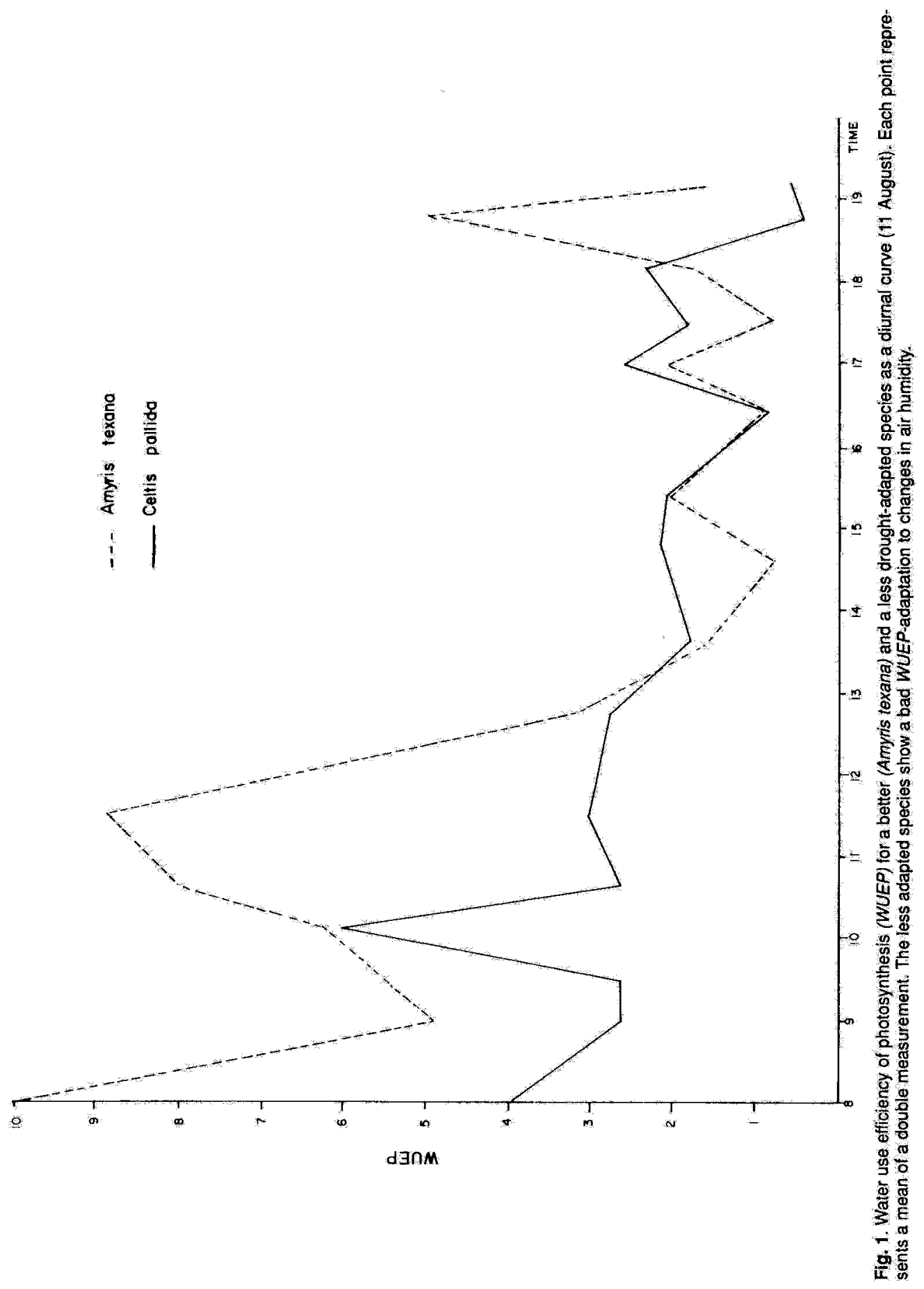




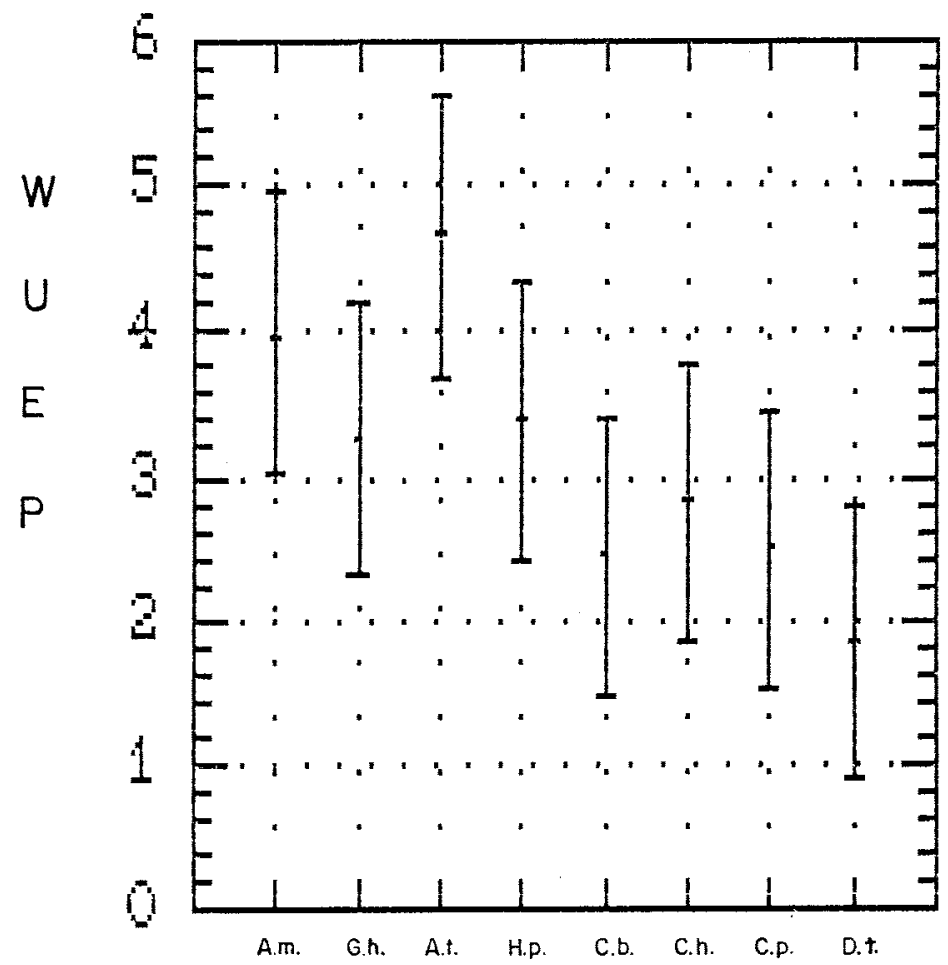

Fig. 2. WUEP on 29 June as day mean for the 8 tested species with least significant differences (each based on 10 repetitions).

less drought-adapted species registered values > $-3.5 \mathrm{MPa}$, indicating that water potential was inversely proportional to WUEP (cf. Schulze, 1986) and that the more drought-adapted species tolerated higher internal water stress.

The mean diurnal photosynthetic rates of all species were relatively low (Table I). The highest instantaneous rate $(29.7 \mu \mathrm{mol}$ of $\mathrm{CO}_{2} \cdot \mathrm{m}^{-2} \cdot \mathrm{s}^{-1}$ ) was achieved by Cordia boissieri on April 29 at 3:10 pm. The other water-wasting species (Condalia hookeri, Celtis pallida and Diospyros texana) also registered high rates under the same conditions, while the remaining species exhibited $20-30 \%$ less photosynthesis but higher WUEPS.
Shaded leaves low in the canopy continued to photosynthesize after fully isolated leaves had closed their stomata. Relative humidity inside the canopy was at times over $10 \%$ higher than above the crown.

The species exhibited various foliar strategies for coping with drought. Helietta parvifolia deactivated chlorophyll, with a consequent yellow discoloration of the leaves under dry conditions. Gochnatia hypoleuca avoided direct insolation by orienting the leaf surface vertically, in the plain of the incoming sunlight. Amyris texana partially rolled its leaves, while $A$. madrensis did not show any leaf response. The remaining species dropped their leaves to varying degrees and were 
therefore ranked low with regard to drought adaptation.

The summary ranking of drought resistance in the 8 species is presented in Table I. Amyris madrensis performed best, while Diospyros texana showed the least adaptation to drought. Species with a summary rank of 6-8 exhibited conservative water use strategies, partially opening their stomates under dry conditions. None of the species can be recommended for planting in drier regions with the exception of Amyris madrensis for wood production and $A$. texana as a forage shrub. These species merit further evaluation in agroforestry trials under semiarid conditions.

\section{Acknowledgments}

The authors wish to thank the W. German Department for Economic Collaboration for the funds to purchase the equipment used in this study.

\section{References}

Carstens A. (1987) Struktur eines Matorrals im semiariden-subhumiden Nordosien Mexikos und auswirkungen von behandlungen zu seiner bewirtschaftung. Beitr. Trop. Subtrop. Landwirt. Forstw. 27

Long S.P. \& Hallgren J.E. (1985) Measurement of $\mathrm{CO}_{2}$ assimilation plants in the field and the laboratory. In: Techniques in Bioproductivity and Photosynthesis. 2 edn. (Coombs J., et al., eds.). UNEP, Pergamon Press, Oxford, pp. 6294

McDermitt D.K. (1987) Photosynthesis measurement system-performance comparison of the Li-6200 and the Li-6000. Licor Inc., Application Note 6200-1. Licor, Lincoln, NE, U.S.A.

Reid N., Marroquin J. \& Beyer-Münzel P. (1989) Utilization of shrubs and trees for browse, firewood and timber in the Tamaulipan thornscrub, northeastern Mexico. For. Ecol. Manage. (in press)

Schulze E.D. (1986) Carbon dioxide and water vapor exchange in response to drought in the atmosphere and in the soil. Annu. Rev. Plant. Physiol. 37, 247-274

Stienen $\mathrm{H}$. (1989) The agroforestry potential of combined production systems in northeastern Mexico. Agrofor. Syst. 7, (in press) 